\title{
The Use of Social Media as a Source of Religious Knowledge Among Doctors in Makassar, Indonesia
}

\author{
MAHMUDDIN \\ ABDUL HALIK \\ Alauddin State Islamic University Makassar, Indonesia
}

\begin{abstract}
In the past, religious knowledge was obtained by reading religious books, but now the development of technology allows religious knowledge to be obtained from social media instead. This article aims to determine the use of social media as a source of religious knowledge for doctors in Makassar, Indonesia. The method used is qualitative, conducted through observations and in-depth interviews with key informants, i.e. members of this social group. Participants were recruited via a local Whatsapp group that contained 66 doctors, 15 of which then became informants in this study. The results of the study show that Facebook, WhatsApp, and Instagram are the most widely used forms of communication media for doctors to obtain religious knowledge. Furthermore, the majority of the religious messages posted in the WhatsApp social group by these health center doctors is for daily instructions and is posted according to the needs of members. The doctors usually do not give many comments on the messages in their social groups to avoid differences of opinion or conflicts between members. If there is a message that may lead to different opinions or even debate, mutual respect becomes their first consideration, because they realize that mutual respect is necessary when living in such a multicultural, multi-ethnic, and multi-religious society. The implications of this research are an increased awareness of how communication media works and an understanding that the mosque is not the only way we can develop and increase our religious knowledge.
\end{abstract}

Keywords: Media, society, religious knowledge, doctors, community.

\section{INTRODUCTION}

Communication is an effective tool in the development of social life today because society communicates in order to fulfil various needs in their lives. The development of communication is currently progressing; one indication of this is that it is much easier for people to fulfill their needs without much effort, simply by pressing a button or tapping a screen. People nowadays can get all their needs met while staying in the comfort of their home.

Furthermore, communication "is a process in which participants create and share information with one another to reach a mutual understanding". It is a kind of social change that involves deliberation and alteration or acceptance of the adopters in the social system. This is so because, when new ideas are proposed, they can be diffused and adopted or rejected, leading to certain consequences in the social system. Adoption of ideas can be slow or fast, depending on the social values, beliefs and culture of a society (Normah Mustaffa, 2011, p.4).

The development of communication media has now become a great tool for various purposes, ranging from promotion, socialization, marketing, and also social life. In addition to meeting these needs, the community also needs entertainment in the midst of their daily 
routine-this can also be obtained through media such as movies, music, sports and so on, and this can be accessed via a single click through YouTube.

The term 'new media' is familiar in our society; yet, among the media practitioners, this term arises when the internet as a means of supporting the communication process turns into a highly developed medium. Many people, young to adult, then feel the urge to access it and it becomes inseparable from today's life. With its various functions, the internet then becomes very attractive for those in need of fast and accurate information. One of the features it offers, favored by many people, is social media or social networking. Social media is part of this new media, which is also a reflection of the popular culture entering Indonesia. The influence of popular culture itself is not always negative; it can be positive from the perspective of its functional values, especially if popular culture can be acculturated well and takes into account religious values (Budianto, 2013).

Communication media in urban communities is important in meeting social needs. One of these needs is religious knowledge, in order to fulfill a sense of spirituality in these urban communities. However, the fulfillment of this spirituality often suffers due to busy work routines that people have to cope with. Therefore, social media then becomes one of the main sources of religious knowledge for urban society today.

The Use of Social Media: Literature Review

Social media has been widely used by everyone from teenagers to adults. Social media is online media, which makes it easy for users to participate, share, and socialize with their community. It has content, such as blogs, social networks, Wikipedia, forums, and the virtual world. Social media also facilitates its users to communicate and interact with one another.

The notion of social media is a set of new tools and collaborations that allow for various types of interactions that were previously not available to ordinary people. Social media is a communication medium where users can fill their content together and use internet-based broadcasting technology that is different from print media and traditional broadcast media. The term social media describes various technologies used to bind people into collaboration and an exchange of information, and interact through web-based message content (Maxmanroe, 2019).

Social Networking sites are the type of social media that is most commonly known to the public and is most widely used by the public. Some of the most used social networking platforms today are YouTube, Facebook, Twitter, Instagram, WhatsApp, Google Plus, and Pinterest (Maxmanroe, 2019).

Social media has received a lot of attention from scholars and they suggest that it is an effort to stay in line with the growing popularity of this new communication platform. Together, social media can easily be considered a defining feature of modern culture and has become a central part of the way people communicate every day, both in their social and professional relationships.

In general, the function of social media is as a media for socialization. This kind of socialization can be performed anytime, anywhere, unlimited to time and space but limited to connections, signals, and internet access. Socialization is the main goal of social media, in which success is in impressing many users who want to socialize and communicate with their relatives. 
In addition, updated information, such as the latest news, gossip, and other information like job vacancies, vehicle buying and selling information, and other information can be easily found on social media. This is very helpful for its users in their daily activities and lives.

Some of the benefits of social media can be seen in various fields (Yuli Yana, 2019). 1) Socializing. The benefit of social media is in accordance with its name, which is to socialize; its main function is as a medium for socializing among individuals. 2) Replacing writing in a Diary. At present, writing in a diary is almost an extinct practice and can be replaced by social media. Many social media users pour their heart out with complaints, sadness, love and happiness. Since it is simple, social media often becomes a place for its users to share their feelings. 3) Bringing old friends together. Social media can sometimes take us to our old friends, childhood friends, business partners who have lost contact, and even siblings who were separated for a long time. 4) Making new friends. This is one of the impressive benefits of social media. On social media, you can make new friends who have similar interests. These new friends can be obtained from the fad results of using social media. 5) Obtaining Entertainment. On social media, you can find interesting things that are entertaining. Starting from funny stories, funny pictures, or interesting quotes that can make you relax and forget your sadness as well as worries. 6) Facilitating hobbies. There are many groups and accounts on social media acting as a gathering place for users with similar interests and hobbies. 7) Providing a variety of updated information. We can obtain various types of information easily on social media and users benefit from this ease of access. 8) Requesting Help. There are hundreds of millions of people using social media. A few hundred or a few tens of thousands of users live around you. This can be used to ask for help from a large online community. 9) Expanding Knowledge. One method of providing educational material on social media in Indonesia is "Kuliah Twitter", colloquially known as Kultwit. Kultwit is defined as a set of tweets that belong to a certain theme or topic, usually containing material about popular science, or tutorials such as how to cook, how to make crafts, etc. 10) Making Money. You can make money from social media by promoting businesses such as creating attractive advertisements so that many potential buyers are interested. In addition, users can also sell goods on social media.

The emergence of new media has influenced ways of communicating in our society. The atmosphere and development of communication in the social world is important because every individual now needs communication media to socialize, which is now known as social media.

Social media combines cyberspace with online service products such as blogs, discussion forums, chat rooms, e-mail, and websites, which has created powerful online communities based on social media (Juju \& Sulianta, 2010, p.1-2).

Facebook, Twitter, Youtube, WhatsApp and Instagram are now the most popular forms of social media in Indonesia and most people spend a considerable amount of time on these sites throughout their day. These social networking sites have been helping people reconnect with friends who have not been around for a long time and who are far away, in addition to help people make new friends. People can easily convey their desires and/or needs through these social media platforms.

Communication needs in the community, which are often referred to as popular society or pop culture, are increasing. The majority of pop culture content is determined by industries that disseminate cultural materials, for example printed media, electronic media, and 
publishing industries, including online news media. Pop culture is not just an aggregate product of industries, but on the contrary, it is the result of the ongoing interactions between these industries and the people in the community who use these products. One of the communities or social groups found in urban communities in Makassar is the community of local doctors. These doctors, as with other people, also feel the need for spiritual guidance. Therefore, to obtain religious knowledge, the use of social media is a necessity for them. This article discusses the use of media as a means to obtain religious knowledge for doctors in Makassar Indonesia.

\section{RESEARCH METHOD}

This research uses a qualitative method, where the researcher acts as the key instrument of investigation. The data collected is triangulated (combined), data analysis is inductive, and the results emphasize meaning rather than generalization (Sugiyono, 2005, p.1). The researcher conducted observations and in-depth interviews with key informants, i.e. members of this social group of doctors in Makassar, Indonesia. There were 66 members in the WhatsApp social group of the public health care doctors, and of this, 15 doctors became informants in this study, acting as representatives of the group. Interviews were conducted by asking a number of questions, either face-to-face or by posting questions to the WhatsApp group. In addition to interviews, observations were made by following the posts in the WhatsApp group for a period of four months.

\section{RESULTS AND DISCUSSION}

In the study of religion, one of the most crucial topics is the relationship between followers of religion in a social context, because every country today is inhabited by a variety of ethnicities, cultures, traditions and religions, which can often create tension and conflict. Mutual tolerance must be fostered within religious activities and in life relating to democracy, justice, culture, and human rights. The need to develop awareness of tolerance is a very important thing to do. In Indonesia, ethnic and religious diversity has led to a mutual understanding between the various communities and its adherents.

In urban communities, awareness of ethnic and religious diversity is a necessity if you do not want to experience anxiety or difficulties, because urban society, especially in the city of Makassar is very heterogeneous. The people of Makassar are a heterogeneous and pluralistic population as the city is inhabited by various ethnicities, religions, cultures, and customs. Therefore, the Makassar community is a multicultural society.

Makassar is the capital of the South Sulawesi Province, previously known as Ujung Pandang Municipality from 1971-1999. Ujung Pandang comes from the word 'Jumpandang', which for centuries has been used to refer to inland people. It was only on October 13, 1999 that the city changed its name back to Makassar, based on Government Regulation Number 86 of 1999. The total area of the city is 175.77 kilometer square. The total population in 2010 was 1,339,374 people, of which 661,379 were male and 677,995 were female (Makassar City Profile, 2019, June 12).

Makassar is different from other regions or other ethnically homogeneous areas, such as Bali and Hinduism. There are ethnic groups of Christian beliefs who originally came from the Toraja tribe living in Tana Toraja Regency. The Tana Toraja community also claims to be indigenous people, heirs of the land of South Sulawesi. There is also a large Chinese population 
in Makassar, and the city has many Chinese buildings including four colorful Buddhist temples and KongHuCu in Chinatown. The historical traces in the form of texts on gravestones in Chinese cemeteries in Makassar (now the central market area) reveal that Chinese people have come to Makassar since the 14th century (Makassar City Profile, 2019). Furthermore, in urban society there are various professions that are filled by people with various kinds of beliefs, religions and ethnicities. In social relations and professions there is a necessity to understand each other and understand one another.

The capacity to understand cultural diversity in various aspects greatly helps achieve the desired goal of mutual respect within the community. In the field of health communication for example, Nora MacLeod-Glover said that cultural competency is comprised of four elements: cultural awareness, cultural knowledge, cultural skill and cultural encounter (Nora MacLeodGlover, 2006). Cultural awareness means becoming sensitive to patients' beliefs, attitudes and behaviours as well as one's own values, biases and prejudices. Practitioners who practice with cultural awareness will consciously and deliberately avoid imposing their own cultural values on their patients. Cultural knowledge is the process of learning about other cultures and views they hold by gaining awareness of the different beliefs, attitudes, behaviours and problemsolving strategies of a variety of cultural groups. Cultural knowledge does not mean memorizing facts about different ethnic or cultural groups; there are great individual differences within all ethic and cultural communities and care should be exercised to avoid stereotyping. Cultural skill is having the capacity to carry out a cultural assessment that includes gathering culturally relevant information about the client's health and incorporating the information to create culturally harmonious interventions. Effective cultural assessments require trust, respect and empathy within the relationship. Cultural encounter is one in which health care providers consciously and deliberately apply their knowledge and skill to provide culturally sensitive care. Culturally sensitive care respects the beliefs, attitudes and cultural lifestyles of patients; it is sufficiently flexible to respond to differences in ethnic values, cultural orientation, religious beliefs and linguistic considerations. Reflecting on past interviews with culturally different individuals can increase awareness of one's own values or biases and also incorporate new culturally relevant knowledge into one's existing knowledge base (MacLeod-Glover, 2006).

The necessity of relationship between ethnic groups or different religious groups is caused by the many tribes, ethnicities, and religions coexisting in Indonesia. If one particular ethnicity or religious follower acts as it they are superior, conflicts may arise. Therefore, awareness of the diversity of cultures and the appreciation of diversity is very important.

The tendency to see a particular religion as a religion of a particular community, if not well understood, can cause friction and conflict. In addition, minor problems occurring between two different ethnic groups who claim to be followers of a particular religion can trigger an even greater conflict. The lack of awareness regarding the existence of different traditions and cultures of other communities will cause anomalies. Therefore, we need an awareness of cultural diversity and tradition. One topic that until now is still being discussed as an effort to overcome the problem of community pluralism is multiculturalism.

For Muslims especially, the issue of multiculturalism is so important, because the Muslim community has spread to various regions and ethnic groups. Their presence and differences in views that arise can either be embraced by each group or school, or are 
vulnerable to conflict. Internally, Muslims must instill a tasamuh attitude to foster mutual respect and accept the differences of the schools. Meanwhile, externally, Muslims face the problem of conflict between Islamic culture and non-Islamic culture. This cross cultural meeting can influence Muslims either negatively or positively.

According to Azyumardi Azra, diversity or multiculturalism is one of the main realities experienced by society and culture in the past, present, and in the future. Diversity should not be interpreted singly, and a commitment to recognize diversity as one of the main characteristics of the people and the nation state does not mean a dislocation, cultural relativism, social disruption, or prolonged conflict in every community, society, and ethnic and racial group (Azra, 2007).

Religions can also produce conflict when present in the midst of a pluralistic society. As in the theory revealed by Marx that in existing reality, different religions or beliefs can cause conflicts. Differences in beliefs and rituals in a religion often become political reasons, economic control, or an effort to dominate certain ethnic groups upon other ethnicities.

Ironically, we also see religion being used as a symbol for people to justify their activities that are not actually based on religious teachings. In this context, religion is used to attract charisma and sympathy for an individual in the eyes of others, but basic religious values are often ignored and they lose their identity as an institution giving dogma.

From the explanation above, it can be concluded that this research is focused on the use of media, the topics accessed and the influence of religious knowledge among doctors. The results of this study can be used to determine the factors that cause doctors' desire to obtain religious teachings and the influence of religious teachings on their lives.

\section{Doctors' Use of Media in Religious Studies}

The Doctors Community in Makassar uses WhatsApp as their main method of communication media, in conjunction with other media such as Instagram, Facebook, blogs. The WhatsApp group shares schedules and information updates. The group consists of public health center doctors in Makassar of a variety of faiths, mainly Muslims and Christians. This shows that the members have different cultural and religious backgrounds as part of a multicultural society.

WhatsApp has become the main communication medium for many people in Indonesia because it is highly effective as a means of communication. Every activity shared on the WhatsApp group of the public health center doctors always gets a positive response from its members. This proves that the members are interested in the content and want to know the activities and schedule of the group.

The use of social media in sharing information is considered a necessity, as one informant said:

There are several reasons we use communication media. First, it is easy, as an example is the calls for meetings without making and delivering invitations. Second, we can save our credits. The online media do not charge us after having an internet connection. Third, we can obtain information faster. Fourth, we can even discuss medication with colleagues. Fifth, discussion about the disease with colleagues and experts is made easier (Fitriani, Interview, March 3, 2019). 
According to Binus (2019), social media has many benefits for our daily lives as follows:

1. Social interaction: in the world of communication, social media is useful as a means to build relationships. Social media facilitates long distance communication because it is operates on a global scale and makes it easy for us to interact wherever we are.

2. Entertainment media: currently, there are many types of social media functioning as entertainment media, one of which is YouTube. We can look for various things to entertain ourselves, ranging from funny stories and pictures, to music. We can look for various interesting things in social networks to entertain us.

3. Information media: we can upload the latest news and other information on the internet to help us access a lot of information.

4. Creativity exploration: Various forms of social media can be used to explore creativity and self-expression, for example writing articles or sharing experiences on blogs

Although social media has many benefits, social media can also have a negative impact on those who overuse it as follows:

1. Lack of direct interaction: social media makes it easy for us to interact in cyberspace and we can forget about direct interaction with the surrounding community. Using social media too much can also make us forget the time and environment.

2. Health problems: many of social media users forget the time, some even get addicted. There are some people who use social media too much and stay up late at night. There are also some people who forget to eat. This is not good because it can have a negative impact on users health.

3. Addiction: social media is fun so it can cause addiction for its users. This can make it difficult for users to separate their daily lives from social media.

However, the use of social media has helped informants to organize daily activities better and to access religious knowledge. The use of social media to access religious studies was stated by one of the informants:

We prefer to use online media to access religious studies rather than listening directly from the preachers due to our tight schedule and daily tasks. We don't have the time to attend religious lectures directly, so we prefer to access religious knowledge in online media (Nur Qalbi, Interview, March 5, 2019).

Although WhatsApp is the main communication medium, to gain more religious knowledge, the informants (doctors of public health centers in Makassar City) also used various kinds of communication media such as social media, television, internet, books, Facebook, Instagram, religious lecturing, tarbiyah, radio, and online groups.

In acquiring religious knowledge, the types of communication media that are more widely used are Facebook, WhatsApp, and Instagram, because these platforms are available on electronic devices or cellphones used every day for communication. In Indonesia, a majority Muslim country, much of this religious material is concerned with Islam and there has been a 
growing trend of religious content on social media since 2014. Some of the issues surrounding the nomination of the head of state or the head of the region cannot be separated from the discussion of Islamic guidance on social media.

The use of communication media is a good strategy for delivering messages to the public because the messages delivered can be easily accessed by users anywhere and anytime. The messages conveyed through the media include religious knowledge that can be general, clear, precise, and takes into account the situation and conditions of its users. One of the informants expressed his interest in one of the preachers:

We are interested in some preachers because they have a special way to send the religious messages. They send the preaching materials not in such a serious manner, well, they even make jokes. It is easy to understand (Aulia, Interview, March 10, 2019).

One of the benefits of accessing online media is that it gives the users choices regarding information, including religious knowledge, as abundant information is available including religious knowledge from various schools that can be accessed in online media. However the availability of various religious views may also pose a problem for users, as they may not have all the background knowledge to fully understand these different views. This problem leads online users to disagree with other users who access different content and this can create conflict if each user does not understand and is not aware of differences of opinion in religious studies.

Some social media users feel the rampant Islamic material they read in the social media era makes them more interested in studying Islam, and helps them to feel that they have a better understanding of Islam and that their daily behaviour is in line with Islamic guidance.

Islamic material on social media is also considered helpful for those who feel they have limited time to attend study forums in person. Of course this has become a positive thing in social life in Indonesia. But on the other hand, there are also concerns that some other communities will grow religious extremism that is associated with an increase in terror in the name of religion in Indonesia, the rise of hate speech, and fake news on social media. This concern also came to the attention of the government which then led to the issuance of rules on hate speech, and the latest issue of religious activity monitoring in schools and Islamic mass organizations emerged.

In a multicultural society, a variety of views, traditions, cultures, and even religions becomes an unavoidable part of life. In the midst of these differences, what is important is the appreciation of each individual or group and, therefore the concept of absolute truth must be abolished. One of the informants stated the attitude:

The religious information obtained through communication media does not lead to conflicts among us because we do not focus on such difference, as we prefer to access information on how to live our lives based on our religious views. It teaches us how to live our daily lives including socialization with others (Eva, Interview, March 7, 2019). 
The frequency of attending religious studies varies amongst the doctors. Some doctors attend it twice a day; some others do that three to four times a day, or even more. Some follow the recitation once a week; some others do that four times a week through online groups. To increase religious knowledge, a non-Muslim informant said:

I attend the church every week, and I follow the daily devotions delivered by my religious leaders three times a week (Eva, Interview, March 7, 2019).

From the description above, the frequency of following religious studies can be considered to be very adequate and meet their needs in accessing religious studies. From all the informants who were the source of this research, on average they attended religious studies at least once or twice a day; this shows a strong desire in these doctors to improve their religious knowledge.

\section{The Topics Accessed}

In general, on social media we can obtain religious knowledge according to our wishes. This ranges from knowledge of religious rituals to knowledge of social, economic and even politic knowledge that has anything to do with religion. Therefore, the media has a very significant function, however it is still individual users who determine what knowledge they seek out and apply in their daily life.

There were three main topics studied, the first being rituals, such as how to do shalat fardhu (obligarory prayer), shalat sunnah (sunnah prayer), sodaqoh (donation), zakat, puasa (fasting), and so on. The second was religious studies on social order include ways of interacting with fellow citizens both in social life and in buying and selling. The third topic related to daily guidance referring to instructions on how to conduct daily life for the informants. Of the three topics above, the informant prefered to take part in studies related to guidance in daily life. One example of this can be seen as follows:

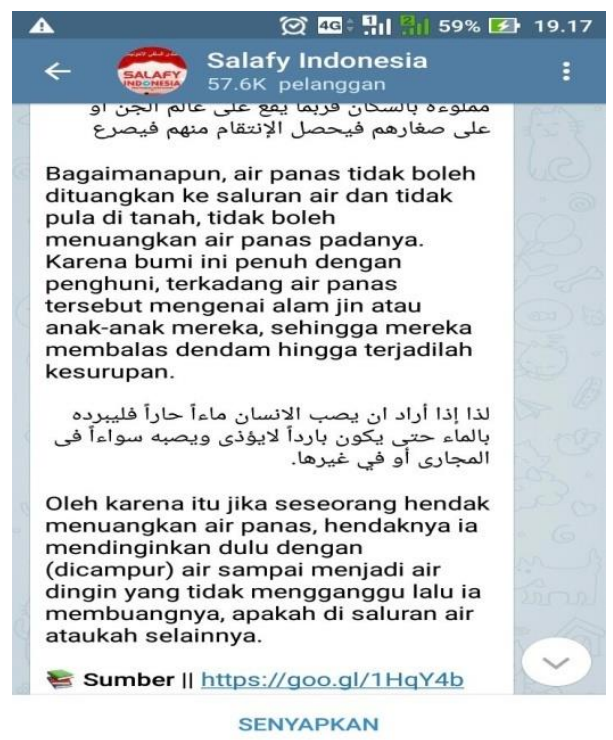

Figure 1: Interactions with fellow citizens in media social 
The topics sometimes have very significant differences of opinions, but as the informants do not emphasize the differences of views and simply focus on the essence they need, such as instructions in everyday life, no conflict occurs between them. Moreover, among its members, there are non-Muslims who can also access information in the Whatsapp group.

From the information above, it can be concluded that the informants have realized the importance of multicultural awareness in everyday relationships, as illustrated in the selection of topics posted in the Whatsapp group. As it is understood that multiculturalism is an awareness of cultural diversity in life, this awareness has helped them to appreciate differences in culture and religion.

It is an undeniable fact that conflict between tribes, religions, and small groups of people are widespread in the country at present. Each group struggles for or maintains its own interests and this leads to a neglect of the importance of co-existence amongst different traditions. To overcome this, an understanding and awareness of the wider community is needed to encourage tolerance and mutual respect among various groups of people.

\section{The Effect of Religious Studies on Informants}

Social media also provides an arena to spread distorted information about hate speech and radicalism. In addition to feeling threatened by other groups, intolerance towards different religious or ethnic groups is caused by the spread of hate speech. "The rapid development of the media in addition to having a positive impact must also be recognized as having a negative impact in relation to intolerance and radicalism in Indonesia," (Pamungkas, 2018). Pamungkas stated that the strengthening of religious conservatism sentiments in the community is not only cultural and ideological expressions, "Furthermore, it is vulnerable to be used by certain actors to obtain economic and political resources," he explained. He also stated that although the social life of the community is relatively tolerant, but there was a politically strong rejection of different religions leaders (Pamungkas, 2018). However, these doctors are not influenced by studies of religion that contain radicalism, because they already have a broad understanding of how to deal with fellow humans despite different beliefs, religions and traditions.

But in terms of searching for religious knowledge on social media, the doctors are very interested and religious studies have an influence on the informants. Interviews proved that informants were influenced by obtaining religious knowledge through social media, in that their understanding of religious teachings increased and this encouraged them to become better human beings. Although one informant said that religious studies only had an effect on increasing knowledge of religious teachings, not that their behviour changed. Meanwhile, for a non-Muslim informant, following religious studies also had an influence on his life and made him a better human being.

One of the benefits is the growth of character or good behavior by glorifying and helping one another, as seen in one informant's statement:

"If we are asked to help in an activity such as helping communities affected by disaster, then we all participate in these activities by way of collecting what they need, such as clothing, snacks, drinks, and so on. Our willingness to help arises because we believe that helping others without distinguishing ethnicity, 
religion, and culture is a commendable act as in the teachings of religion we know" (Damayanti, Interview, March 18, 2019).

From this explanation, it can be concluded that mutual assistance among community members is an effect of the religious knowledge they gain from religious studies they attend and the religious knowledge they obtain via social media. Therefore, these doctors are not at all interested in issues of religious fanaticism, radicalism, and religious conservatism, because they have good insight into the essence of religious teachings. Studies that raise concerns about being influenced by religious radicalism material on social media can be avoided if the recipients already have a good basic knowledge of religion before they access religious lessons on social media.

Thus, the strategy behind using social media, especially in religious studies, by the doctors through the WhatsApp social group is as follows:

1. The majority of the messages posted are instructions on how to live one's daily life.

2. The messages posted are general, and according to the needs of the members of the social group.

3. The members of the group do not comment too much on the message posted, so it does not cause differences of opinion or conflicts between members of the social group.

4. If the messages posted lead to debate, then the members make mutual respect the top priority because they realize that mutual respect in the midst of differences in religion, culture, ethnicity is the most important and is suitable with the doctrine or dogma and medical ethics they believe saying that every doctor must provide services to all patients regardless of ethnicity, culture, religions, and beliefs. It is this doctrine that leads them to respect each other.

In accessing religious studies personally through other sources from the online media, some informants prefer preachers who deliver the studies not too seriously or with some jokes. Thus, it can be concluded that the communication strategy well accepted by audiences, especially informants in this study, is the one that does not need much thought or analysis. In other words, the informants prefer religious studies to be delivered based on their needs and that the content is easy to understand.

\section{CONCLUSIONS}

From the discussion, it can be concluded that doctors in public health centers in Makassar prefer having online media to access religious studies rather than attending studies directly, as doctors tend to have tight schedule. The most widely used forms of social media by these doctors in obtaining religious knowledge are Facebook, WhatsApp, and Instagram.

Although WhatsApp is the main communication medium, to gain more religious knowledge, the informants (doctors of public health centers in Makassar City) also used various kinds of communication media such as social media, television, internet, books, Facebook, Instagram, religious lecturing, tarbiyah, radio, and online groups.

Furthermore, the communication strategies used are as follows. First, the majority of the religious messages posted in the WhatsApp social group by these health center doctors is 
for daily instruction and is posted according to the needs of members. The doctors usually do not give many comments on the messages in their social groups to avoid differences of opinion or conflicts between members. If there is a message that may lead to different opinions or even debate, mutual respect becomes their top priority.

The implications of this research are an increased understanding of the use of communication media in multicultural communities in accessing information, especially doctors, such as for increasing religious knowledge. This is very significant, and can increase our knowledge of models of communication media use and makes it apparent that we can obtain religious knowledge from many sources, and not only from mosques.

\section{ACKNOWLEDGEMENT}

This research was supported by Faculty of Ushuluddin, Philosophy and Politics, State Islamic University Alauddin Makassar, Indonesia through DIPA APBN 2018.

\section{BIODATA}

Mahmuddin, is a lecture in Islamic studies and Islamic thought, Faculty of shuluddin, Philosophy and Politics, State Islamic University Alauddin Makassar, Indonesia. He specialized in Islamic Studies and Islamic Movement. Email: mahmuddin.harun@uin-alauddin.ac.id

Abdul Halik, is a lecture in communication, Department of Communication, Faculty of Da'wa and Communication, State Islamic University Alauddin Makassar, Indonesia. PhD in mass communication and political communication from UNPAD (Padjajaran University) Bandung. Email: kacomandar@yahoo.co.id 


\section{REFERENCES}

Awad, T. A., \& Alhashemi, S. A. (2012). Assessing the effect of interpersonal communications on employees commitment and satisfactions. International Journal of Islamic and Middle Eastern Finance Management, 5.

Azra, A. (2007). Kebutuhan pendidikan multikultural. Retrieved on January 24, 2019, from http://www.pelita.or.id/baca.php?id=2667

Bajari, A., \& Saragih, S. T. (Ed.). (2010). Teori dan praktek komunikasi kontemporer. Bandung: Remaja Rosdakarya.

Baso, A. (2002). Plesetan lokalitas: Politik pribumisasi Islam. Depok: Desantara.

Berger, C. R, Roloff, M. E., \& Roskons-Ewoldsen, D. R. (2014). Handbook ilmu komunikasi (Terjemahan D. S. Widowatie). Bandung: Nusamedia.

Binus. (2019). Media sosial dalam kehidupan sehari-hari. Retrieved from https://communication. binus.ac.id

Bohang, F. K. (2017). Di Indonesia, jumlah pengguna line pepet Facebook. Retrieved February 10, 2017, from http://tekno.kompas.com/read/2016/09/03/09490637

Budianto, H. (Ed.). (2013). Komunikasi Indonesia untuk membangun peradaban bangsa. Jakarta: Puskombis.

Budiyono. (2016). Media sosial dan komunikasi politik: Media sosial sebagai komunikasi politik menjelang Pilkada DKI Jakarta 2017. Jurnal Komunikasi, 11(1).

Devito, J. A. (2011). Komunikasi antarmanusia (Terjemahan Abus Maulana). Pamulang: Karisma.

Effendy, O . U. (1984). Ilmu komunikasi: Teori dan praktek. Bandung: Remaja Rosdakarya.

Emma Mohamad. (2007). Communication strategies and media role to promote successful breastfeeding. Jurnal Komunikasi: Malaysian Journal of Communication, 23.

Ezaleila Mustafa, \& Azizah Hamzah. (2012). Media baharu yang baharu: Trend penggunaan jaringan sosial dalam kalangan pengguna di Malaysia. Jurnal Pengajian Media Malaysia, 13(2).

Hamad, I. (2004). Konstruksi realitas politik dalam media massa: Sebuah studi critical discourse analysis terhadap berita-berita politik. Yogyakarta: Granit.

Haryatmoko. (2003). Etika politk dan kekuasaan. Jakarta: Kompas.

Jejak-jejak Tionghoa di Makassar. (n. d.). Daeng Gassing. Retrieved on February 29, 2019, from https://daenggassing.com/kota/makassar/jejak-jejak-tionghoa-di-makassar/

Juju, D., \& Sulianta, F. (2010). Branding promotion with sosial networks. Jakarta: PT. Elex Media Komputindo.

Komala, L. (2009). Ilmu komunikasi. Perspektif, proses, dan konteks. Bandung: Widya Padjajaran.

Kreps, G. L., \& Kunimoto, E. N. (1994). Effective communication in multicultural health care settings. Thousand Oaks: SAGE Publications.

Krupnikov, Y. (2014). How negativity can increase and decrease voter turnout: The effect of timing. Political Communication, 31(3).

Liliweri, A. (2007). Dasar-dasar komunikasi kesehatan. Yogyakarta: Pustaka Pelajar.

. (2011). Komunikasi: Serba ada serba makna. Jakarta: Kencana. . (2014). Sosiologi dan komunikasi organisasi. Jakarta: Bumi Aksara. 
MacLeod-Glover, N. (2006, September). Communication in a multicultural society, the Canadian Council on continuing education in pharmacy. Communications Centre CE.

MacNamara, J. (2010). Public relations and the social: How practitioners are using, or abusing, social media. Asia Pacific Public Relations Journal, 11(1).

Maxmanroe. (n. d.). Pengertian media sosial secara umum, fungsi, tujuan, jenis sosmed. Retrieved from https://www.maxmanroe.com/vid/teknologi/internet/pengertianmedia-sosial.html

Middleton, A., Ahmed, M., \& Levene, S. (2005). Tailoring genetic information and services to clients' culture, knowledge and language level. Nursing Standard, 20(2), 52-56.

Mukhtar El-Kasim, \& Syed Arabi Idid. (2017). PR practitioners' use of social media: Validation of an online relationship. Jurnal Komunikasi: Malaysian Journal of Communication, 33(1).

Normah Mustaffa, Faridah Ibrahim, Wan Amizah Wan Mahmud, Fauziah Ahmad, Chang Peng Kee, \& Maizatul Haizan Mahbob. (2011). Diffusion of innovations: The adoption of Facebook among youth in Malaysia. The Innovation Journal: The Public Sector Innovation Journal, 16(3).

PakarKomunikasi.com. (n. d.). Teori strategi komunikasi - Pengertian - Landasan. Retrieved March 21, 2019, from https://pakarkomunikasi.com/teori-strategi-komunikasi

Parrott, R. (2004). Emphasizing "communication" in health communication. Journal of Communication, 54(4).

Pemungkas, C. (2018, October 29). LIPI ungkap fenomena sosial intoleransi dan radikalisme. LIPI. Retrieved from http://lipi.go.id/siaranpress/LIPI-Ungkap-Fenomena-SosialIntoleransi-dan-Radikalisme/21357

Ruben, B. D., \& Stewart, L. P. (2013). Komunikasi dan perilaku manusia (Terjemahan Ibnu Hamad). Jakarta: Rajawali Pers.

Siburian, T. A. (2013). The effect of interpersonal communication, organizational culture, job satisfaction, and achievement motivation to organizational commitment of state high school teacher in the district Humbang Hasundutan, North Sumatera, Indonesia. International Journal of Humanities and Social Science, 3(12).

Sugiyono, P. (2005). Memahami penelitian kualitatif. Bandung: Alfabeta.

Suparlan, P. (n. d.). Menuju Masyarakat Indonesia yang Multikultural. Retrieved on December 20, 2018, from http://journal.ui.ac.id/index.php/jai/article/view/3448

van der Ven, C. Mentransformasikan budaya. In, Transformasi agama dan budaya di tengahtengah kekerasan social. LINTAS - Jurnal Forum Dialog (FORLOG) Antarkita Sulawesi

Selatan, (Edisi 1, Maret 2003). Retrieved from

https://web.archive.org/web/20080824203019/http://www.geocities.com/forlog/lintas 1corrie.htm

Wall, M. (2017). Mapping citizen and participatory journalism. Journalism Practice, 11(2-3).

Waloeyo, J. Y. (2010). Twitter best sosial networking. Yogyakarta: Andi dan Elcom.

Wright, D. K., \& Hinson, M. D. (2015). Examining social and emerging media use in public relations practice: A ten-year longitudinal analysis. Public Relations Journal, 9(2).

Yana, Y. (2015, February 12). 10 manfaat sosial media di berbagai bidang. Manfaat.co.id. Retrieved https://manfaat.co.id/10-manfaat-sosial-media-di-berbagai-bidang 